\title{
COVID-19 - reflections on the surprise of both an expected and unexpected event ${ }^{1}$
}

Johannes (Joost) PLATJE

WSB University in Wroclaw, Wroclaw, Poland

Jeffrey A. HARVEY

Netherlands Institute of Ecology, Wageningen, The Netherlands, and

Vrije University, Amsterdam, The Netherlands

\section{Lez Rayman-BACCHUS}

\section{University of Winchester Business School, Winchester, UK}

Abstract:

Aim: This paper reflects on the COVID-19 epidemic from the perspective of small probabilities and the difficulty of predicting similar events. Against the background of basic economic principles, the importance of the precautionary principle for crisis management is discussed, as well as potential consequences of this epidemic.

Findings: The authors argue that whilst the epidemic as such was unexpected, in future countries should be prepared for such stochastic events to happen. This requires a precautionary approach. When society is not prepared for such a calamity, or waits too long to implement measures to deal with it, the social and economic costs may be very high - much higher than 'hedging bets' and losing. The article reflects on different issues which are meant for further discussion on unpredictable future threats. One important issue is the uncertainty created by this event. This increases the likeliness that something unexpected can appear in the near future, creating the need for research and discussion on public and government responses to these events. Being aware of such challenges increases the likeliness of

\footnotetext{
${ }^{1}$ This paper is non-refereed, as it reflects on the actual situation. Authors are invited to contribute to the discussion and submit their reflections to this journal.
}

Correspondence address: Johannes (Joost) PLATJE, WSB University in Wrocław, ul. Fabryczna 29-31, 53-609 Wrocław, Poland. E-mail: johannes.platje@wsb.wroclaw.pl. E-mail: j.harvey@nioo.knaw.nl (Jeffrey A. Harvey), E-mail: Lez lezmichael@gmail.com (Lez Rayman Bacchus).

Received: 27.03.2020, Accepted: 28.03.2020

doi: http://dx.doi.org/10.29015/cerem.874 
society and people to be prepared for such developments. It is concluded that the current crisis brings forward the question whether the current political-economic system and globalization makes future pandemics more likely, and whether a radical change towards a more locally oriented economy provides solutions that minimize the likelihood or frequency of future pandemics.

Keywords: Black Swans Management, precautionary principle, non-linearity, crisis management, Coronavirus disease (COVID-19)

JEL: F69, H12, Q56

\section{Introduction}

The Covid-19 pandemic has created a crisis situation, in particular, in Europe and the USA. For many people, including scientists and politicians, the current epidemic appears to have come as a complete surprise. One could argue whether the current situation is a good example of a so-called Black Swan (Taleb 2007): an unexpected, very unlikely event that will have profoundly negative consequences for society and the global economy. However, there is a long and well-documented history of epidemics that have decimated earlier human populations (MPHonline 2020). And in the current process of globalization, it has been argued that the appearance of random events can pose greater threats due to the interconnectiveness of economic and political systems (Taleb 2012; Casti 2013). As Taleb wrote in his book "the Black Swan" in 2007:

"As we travel more on this planet, epidemics will be more acute - we will have a germ population dominated by a few numbers, and the successful killer will spread vastly more effectively. ... I see the risk of a very strange virus spreading throughout the planet" (Taleb 2007: 317).

As such, this event was an unexpected event, that could have been expected in one or the other form to appear one day. Ford (2020) states that the threats were already known in November 2019. In other words, we may talk about an unexpected event that could have been expected. It may be rather ignorance of the possibility of such events to happen that lead to lack of policy and preparation (spare capacity, buffers in health care).

As Taleb (2007) argues, small probability events with potentially high impacts are often ignored or downplayed, and considered to be a one in a hundred or thousand year event. Their stochasticity thus makes it very difficult for society to 
prepare for them., leading to responses that are reactive rather than proactive. Furthermore, a problem of dealing with such events is that it is very difficult or rather impossible to prove such an event has been prevented, despite efforts and costs that are clearly visible (Kahneman 2011). However, even when believing that such events can happen, there is a difference between being aware of this, and really feeling and experiencing such a situation. People having no experience with a warlike situation, or other types of crises, may have difficulties envisaging such a situation. This creates serious challenges in preparing for different types of threats, as well as an Early Warning System for potentially disastrous events (see Platje 2019; Platje, Zepeda Quintana 2019).

In this reflective paper, we provide some theoretical considerations for thought and further discussion. First, we will discuss the issue within an economic context. The main idea is that standard cost-benefit approaches do not catch the issue of preparation for potential disasters, as this approach may easily lead to the neglect of the potential threats of such an event, while, following Taleb (2007), awareness of such events is an important part of the solution. Afterwards, the importance of the precautionary principle is discussed on practical examples. Finally, some potential effects of the epidemic are discussed. While many effects are visible now or will become visible in the near future, the uncertainty created by the epidemic should make us aware that many different scenarios are possible. While many predictions probably will not become reality, also here awareness of the problem may make people and society more prepared for the new challenges.

\section{Some general economic principles}

A flaw of the cost-benefit approach in economics is that it does not provide political and economic systems with instruments that can handle rare, stochastic events. As a consequence, the cost of such an event can be substantial, and even lead to serious damage to political and economic systems (compare Taleb et al. 2014). This approach is strongly related to system theory, which can help to prevent negative side-effects of diffenent types of policy (Sterman 2000). 


\section{Johannes (Joost) PLATJE, Jeffrey A. HARVEY, Lez Rayman BACCHUS}

Standard economic theory states that there is no such a thing as a free lunch - by making choices, we need to sacrifice something else. This leads to a classic trade-off in prioritization. Now, the question becomes, whether this is a metaphorical choice between buying a steak or a hamburger, or between investing in a holiday resort or airports, or education and health care infrastructure. Or in case of an overcrowded hospital between treating one patient or another, either of whom might die without treatment. Investment policy, based on cost-benefit analysis, may try to catch the possibility of epidemics to appear. However, when such a situation has not happened for a longer time, policies for improving efficiency in health care may lead to different kinds of unseen fragilities, which become visible in the case of an unexpected event, e.g., an epidemic, which could have been expected to appear one or the other day. As Harari (2019) argues, the fact that we have managed many threats of epidemics does not happen they cannot appear in the future. However, this is easily forgotten in when health care is dealing with the many short-term or even immediate challenges.

As mentioned, epidemics are unexpected events, which consequently could be expected to appear unpredictably in space and time. The long-term impacts of epidemics are difficult to predict due to this high level of uncertainty. However, this is an example of when all is considered to be fine and that no threats exist (like economists believing in permanent growth and the idea of perfect markets), it is almost inevitable that a 'rabbit will jump out of the hat' sometime, somewhere. And this posits the question whether this is a reversible, manageable problem, or an irreversible, system-threatening issue. As such, this issue is related to the idea that non-linearity can threaten the sustainability of different types of socio-economic sytems.

As Taleb $(2005,2012)$ shows, there is a problem with unseen evidence. When providing aid for a disaster area, this reduces the funds, and in turn the physical resources, that could be allocated for other areas. For example, when a hospital is overcrowded, this reduces the possibility of treating other illnesses. This may be the case with people with a heart attack or after an accident, where the ambulance cannot come in due time. Or people who need surgery will be treated later when facilities are not available, which in turn can have negative health effects. Of course, 
the impact of such a situation depends on the period such a situation lasts. Furthermore, a question is how these experiences influence the mindset of people. We are not psychologists, but we can imagine that a traumatic situation experienced by many people may have a long-lasting impact. This may also change their risk perception, as with people who have experienced different financial crashes compared with people who have only experienced a growing economy and concomitant increase in welfare and well-being. Depending on the institutional and economic setting of particular countries, this can have impacts that are difficult to predict in the future.

As Tieleman et al. (2020) argue, in the early stages of the COVID-19 epidemic in Italy, The Netherlands adopted a rather lenient, lacklustre approach based on a 'business as usual' scenario. No travel restrictions were implemented with northern Italy only weeks before the spread of the pandemic, and pre-emptive warnings by some epidemiologists were ignored, until the 'chickens came home to roost'. To be fair, the Dutch response was barely different from that of most other western industrialized nations in Europe and North America. For many weeks, COVID-19 was presented almost as a "normal flu" with a low death rate $(<2 \%)$. However, it was rarely mentioned that the virus was novel, and thus that no-one had developed immunity to it, while the rapid spread of the virus wold inevitably lead to a large group of infected people, with a mortality rate that could lead to a large amount of deaths when taken cumulatively. Moreover, it glossed over the fact that a $2 \%$ death rate is up to 20 times higher than the $0.1 \%$ rate of a "normal flu in the USA" (Rettner 2020).

Tieleman et al. (2020) expect the epidemic to last at least another 7 weeks, which could lead to millions of people getting ill; some pessimistic estimates suggest that $60-70 \%$ of the populations of some countries could become infected by COVID-19 in the coming months before a vaccine is available if measures to contain it are unsuccessful (Smith 2020). If this in indeed true, then tens of millions of people, mostly vulnerable groups such as the elderly and those with pre-existing medical conditions, could die across the world. This shows that, in accordance with what Taleb $(2007,2012)$ argues, awareness of small probability, high impact events is essential in preparing for potential crises and proper crisis management. 
Johannes (Joost) PLATJE, Jeffrey A. HARVEY, Lez Rayman BACCHUS

\section{Precautionary principle}

Based on reading a wide variety of media sources, we get the impression that the mainstream and social media are currently full of COVID-19 commentaries from both experts and non-expert pundits alike: the range of opinions expressed is enormous. Some express optimism that measures implemented by most countries are working and that the virus can and will be contained in several months; others argue that current measures are an example of 'too little, too late', that we are in it for the long haul and that the future months are going to be be extremely grim. These opinions are nothing more than that, given the vast number of unknowns. There are so many variables that will determine how this all plays out. These not only involve the success of the current measures, but on the biology and ecology of the virus itself.

This brings us to the precautionary principle, which means that when there is uncertainty or lack of information on the impact of an event, which can lead to serious damage, measures should be taken to prevent such a situation to appear. In other words, itshould be applied when events associated with calamities can damage the functioning of a system seriously, or even destroy it. For example, when an innovation can lead to irreversible consequences for, e.g., human health or the ecosystem, scientific proof is needed of lack of harm. Here lack of action is the result (Taleb et al. 2014).

In the context of the current corona crisis, an important issue appears, namely which system is threatened. The health care system for sure, in the short run. But socio-economic systems can be threateded in the long-run. As Anderson et al. (2020) argue, there is in fact a trade-off between preventing deaths from COVID-19 and prevention of negative economic consequences. The authors argue that human life is most important for citizens. However, from the economic point of view, the question is, should human life be saved at any cost? For many this may sound horrible, but considering the example provided above on hospitals making choices whose life to save, this issue is relevant. When considering the unseen consequences of any kind of activity, preventing as many deaths as possible may have serious economic consequences. 
While the spread of a virus may be considered a natural event, especially in a globalized world, the impact depends on how society deals with the threat.This is not only related to culture and good governance, but also, as Kelman (2020) argues in a blog, on "shoddily built infrastructure, breaking or not having planning regulations, not being able to afford or not having insurance, poor communication of warnings" as well as ignorance of advice and information from experts and poor information provision to society. Another factor that can limit the spread of the virus is general access to health care, as in case of a private health care system, and unpaid sick leave that allows people to remain at home in semi-quarantine. One of main problems in the United States is that millions have no health insurance (Gilmer et al. 2005), the poor not only may not try to find medical onsult, but also undertake activities to obtain a source of income, and many others are only paid when they working, forcing them to turn up to jobs when they are ill (Chen 2016) thus increasing the spread of the virus.

Other important elements of dealing with such a crisis situation are (Anderson et al. 2020): experience, like China, Singapore and Hong Kong, social distancing, isolation and quarantaine which can seriously enhance the containment of the epidemic. Also the number of tests carried out are important for obtaining reliable data and developing policy to deal with the epidemic (Karczmarewicz 2020). Indeed, several Asian countries that experienced the SARS COVID-1 infection in 2003 responded proactively by implementing measures before the viral outbreak in China had spread very far. Taiwan, for example, implemented severe travel restrictions to Chinese nationals as early as January (Chinazzi et al. 2020). If other nations around the world had taken similar measures, instead of maintaining a business-as-usual scenario, we might not be in the predicament that we are now. Public trust in government institutions may have been severely damaged by the lax response to the crisis. However, given that many people are highly skeptical of governments most of the time, it is hardly surprising that they place little faith in current measures to contain COVID-19. In fact, this may also explain why some people in Europe and North America are openly flouting government advice in containing the spread of the virus. Recent evidence shows groups of people meeting in bars, cafes, on beaches or in other public places even in Italy, where the effects of 


\section{Johannes (Joost) PLATJE, Jeffrey A. HARVEY, Lez Rayman BACCHUS}

the pandemic have been most severe. The libertarian ethos that pervades much of western society may indeed hinder efforts to 'dampen the pandemic curve'.

Another main reason for failure of the containment strategy is the limited capacity of health care systems. As discussed earlier, when too many patients are in the intensive care at any one moment, there will be a lack of beds, equipment, staff, etc. This leads to reduced health services for other ill, with all of its consequences. This problem is strengthened when there is a lack of co-operation between hospitals and regions, as regions with excess capacity can relief the troubles in the disaster area. However, this also creates the threat that when patients need intensive are in hospitals in non-infected regions, the capacity for delivering health care services to their patiens may also suffer there. Added to this, contact with patients increases the risk for health care staff to become infected, reducing the capacity of hospitals to deal effectively with the heavily ill (Pan et al. 2020). As the virus may be active for more than a year, and finding a vaccination may take 12-18 months (including medical testing) (Andersson et al. 2020), the strength of quick isolation, quarantaining and social distancing increases in importance, as it can significantly reduce the doubling time of the amount of infected people (Wilder-Smith, Freedman 2020).

\section{Some (potential) consequences of the epidemic}

The closure of many production facilities as well as shops, restaurants, etc., are likely to have a huge impact on the unemployment rate, cause negative economic growth, while the stock markets declined by about 30\% (Amadeo 2020). The OECD has also predicted that the effects of the virus will be far greater than the financial crisis of 2008, and far more long-lasting (Sapovadia 2020). The decline in value on the financial market, declining national income and the increasing pressure on government budgets, will put also pressure on pensions and public goods and services. The dependency on tourism and exports may also lead to different scenarios for different countries. 
Another example of a potential consequence is that highly developed countries may try to employ more specialists from other countries in order to deal with future short-term threats, creating a capacity problem in the countries "exporting" these specialists. This, except for the current negative impact on public health, also reduces the capacity of some countries to deal with possible future epidemics. Furthermore, as viruses do not recognize borders, this may increase the probability of future epidemics as well, exacerbated by globalized trade and increasing interconnectiveness (Taleb 2012).

The institutional consequences of the COVID-19 epidemic are hard to predict. The uncertainty may create a kind of institutional vacuum, where the existing institutions (rules of the game (North 1990)) do not apply completely and may be difficult to enforce (see Van de Mortel 2000; Platje 2004). Examples of a complete institutional vacuum are Arabic countries after the revolutions in 2011, where strong groups took over the power structures (Harari 2019). Naomi Klein (Vice 2020), in an interview on the current situation, argues that „These are the perfect conditions for governments and the global elite to implement political agendas that would otherwise be met with great opposition if we weren't all so disoriented." While limitations on different types of freedom are necessary in democratic societies in case of threats to the functioning of society, they should be withdrawn after the threats disappear, like in the case of 9/11 (Etzioni 2018). However, unpleasant surprises may increase in frequency in future. An issue that requires serious consideration is whether the existing uncertainty will not be used by the economically powerful to permanently change the rules in their own advantage, and/or to strenghten their economic position, which is turn contributes to increasing inequalities. As markets inherently are more random and rough than is often assumed (Mandelbrot, Hudson 2008), and extreme events with low probability will always appear at some time (Taleb 2007, 2012), this issue will always be relevant when assessing the stability and incentives for change in a capitalist society.

An interesting exercise is, what would happen in the short term when one of the following activities would disappear (compare Taleb 2012). For example, what would happen if university professors would suddenly stop working? Or researchers stopped working? Or garbage collectors stopped working? etc. In the last case, in the 
short term, the effects will become directly visible. When not teaching students, the effects on human capital become visible only in the longer term. When stopping broadscale scientific research, this reduces the capacity to deal with future epidemics and other unexpected events, The activities mentioned below cannot be removed without seriously damaging the functioning of society. They have what can be defined as good public functions, as their effects are beneficial for the whole of society. They are also intimately interconnected. For example, without transport, trade is impossible (Rydzkowski, Wojewódzka-Król 2000) and markets would stop functioning (compare Adam Smith, third chapter of his Wealth of Nations (1998 [1776]).

Examples of activities necessary for the functioning of a society in such a crisis are (Rijksoverheid 2020): health care, teachers providing distance education and taking care of children of parents working in the sectors mentioned here, public transport, the supply and distribution chain of food, energy supply and distribution, water supply, management of dangerous waste such as nuclear waste, waste management, child care, media and communication as an element of good governance (acess to information), police, military, fire brigade, government agencies involved in social services for the unemployed, ill etc., telecommunication, online banking services, internet services, etc. As Remuzzi and Remuzzi (2020) write, "[i]t is often the low paid providers of the public goods that have to keep the economy running." Clearly, their role in economic recovery will be as vital as ever in the wake of the COVID-19 epidemic.

\section{Concluding remarks}

It is difficult to predict what is likely to happen in the future. The current COVID-epidemic may show the fragilities in the national and global economies. In other words, weakest links and vulnerabilities. This creates an opportunity to reflect on how to deal with such events in the future. The central point is that unexpected events can be expected (Taleb 2012). The random events, as mentiones, make vulnerabilities in political, social and economic systems visible. The high 
uncertainty appearing during and in the aftermath of such events may trigger off changes that can go into different directions.

For example, a question is whether the Schengen agreement may collapse due to the crisis. Maybe not, but a possible scenario is that when different countries in the EU have different policies of detecting infections, this may be used for continuing restrictions on free travel based on fears for public health. The crisis creates the threat of power enlargement for strong interest groups. To a global kind of oligarchic capitalism, accompanied by increasing nationalism and demise of democratic societies. However, there may also appear opportunities to galvanize society towards and more locally thinking, egalitarian economic system which can deal with other challenges to sustainable development such as climate change and resource depletion. Most important maybe is a discussion on whether the current political-economic system and globalization makes future pandemics more likely, and whether a radical change towards a more locally oriented economy provides solutions.

\section{References}

Amadeo K. (2020), How does the 2020 stock market crash compare with others?, "The Balance", https://www.thebalance.com/fundamentals-of-the-2020-market-crash-4799950 [26.03.2020].

Anderson R., Heesterbeek H., Klinkenberg D., Hollingsworth T.D. (2020), How will country-based mitigation measures influence the course of the COVID-19 epidemic?, "The Lancet", 09 March 2020, https://doi.org/10.1016/S0140-6736(20)30567-5 [11.03.2020].

Casti J.L. (2013), X-Events - complexity overload and the collapse of everything, Harper Collins Publishers, New York.

Chen M-L (2016), The growing costs and burden of family caregiving of older adults: A review of paid sick leave and family leave policies, "The Gerontologist", vol. 56 no. 3, pp. 391-396, https://doi.org/10.1093/geront/gnu093.

Chinazzi M., Davis J.T., Ajelli M., Gioannini C., Litvinova M., Merler S., y Piontti A.P., Mu K., Rossi, L., Sun K., Viboud C. (2020), The effect of travel restrictions on the spread of the 2019 novel coronavirus (COVID-19) outbreak, "Science", preprint.

Etzioni A. (2018), Law and society in a populist age - balancing individual rights and the common good, Bristol University Press, Bristol.

Ford N. (2020), Hunt and Morrison were warned about coronavirus in late November and did nothing an important letter to the editor, "The Bulletin", https://medium.com/@narelleford/wednesday-postda60561dfa40 [26.03.2020]. 


\section{Johannes (Joost) PLATJE, Jeffrey A. HARVEY, Lez Rayman BACCHUS}

Gilmer T., Kronick R. (2005), It's the premiums, stupid. Projections of the uninsured through 2013: the number of uninsured Americans is projected to increase by eleven million in the coming

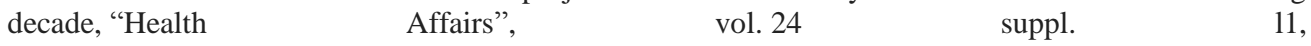
https://www.healthaffairs.org/doi/full/10.1377/hlthaff.W5.143 [28.03.2020].

Harari Y.N. (2019), Sapiens - a brief history of humankind, Vintage, London.

Kahneman D. (2011), Thinking, fast and slow, Penguin Books, London.

Karczmarewicz S. (2020), Covid-19 w Polsce. Azjatycki sukces czy włoska hekatomba? Który scenariusz sobie szykujemy?, "Polityka", 14 March 2020, https://lekarski.blog.polityka.pl/2020/03/14/covid-19-w-polsce-azjatycki-sukces-czy-wloskahekatomba-ktory-scenariusz-sobie-szykujemy/?fbclid=IwAR1v5P3qeXRAKPwWaS2OCw7vEQE49JSAzcar99I8hgNBG1ZoLllhiwgK18 [16.03.2020].

Kelman I. (2020), A professor of disasters and health on COVID-19, http://nautil.us/blog/a-professor-ofdisasters-and-health-oncovid_19?fbclid=IwAR2IxGEaBVXTFqe8oQi12aCqyYjpODxwY5QOtX9ME1WEiswMCG8wTL7zs jY [24.03.2020].

Mandelbrot M., Hudson R.L. (2008), The (mis)behaviour of markets, Profile Books, London.

MPHonline (2020), Outbreak: 10 of the worst pandemics in history, https://www.mphonline.org/worstpandemics-in-history/ [26.03.2020].

Mühleisen M. (2020), Coronavirus economic planning. Hoping for the best, prepared for the worst, 12 March 2020, https://blogs.imf.org/2020/03/12/coronavirus-economic-planning-hoping-for-the-bestprepared-for-the-worst/ [14.03.2020].

North D.C. (1990), Institutions, institutional change, and economic performance, Cambridge University Press, Cambridge.

Pan L., Wang L., Huang X. (2020), How to face the novel coronavirus infection during the 2019-2020 epidemic. The experience of Sichuan Provincial People's Hospital, "Intensive Care Med.", vol. 46, pp. 573-575.

Platje J. (2004), Institutional change and Poland's economic performance since the 1970s - incentives and transaction costs, CL Consulting i Logistyka, Wrocław.

Platje J. (2019), The capacity of companies to create an early warning system for unexpected events an explorative study, in: Transactions on computational collective intelligence, vol. XXXIV, LNCS 11890, Nguyen N.T. et al. (eds.), Springer, Berlin, pp. 1-16.

Platje J., Zepeda Quintana D.S. (2019), Business sustainability and early warning systems, in: Encyclopedia of sustainability in higher education, Leal Filho W. (ed.), Springer Nature Switzerland, Basel.

Remuzzi A., Remuzzi G. (2020), COVID-19 and Italy: what next?, “The Lancet”, 13 March 2020, https://doi.org/10.1016/S0140-6736(20)30627-9,

https://www.thelancet.com/journals/lancet/article/PIIS0140-6736(20)30627-9/fulltext [15.03.2020]. 


\section{CORONAVIRUS DISEASE AND THE PRECAUTIONARY PRINCIPLE ...}

Rettner R. (2020), How does the new coronavirus compare with the flu?, "Live Science", 25 March 2020, https://www.livescience.com/new-coronavirus-compare-with-flu.html [26.03.2020].

Rijksoverheid (2020), Overzicht van cruciale beroepsgroepen tijdens de COVID-19 uitbraak, https://www.rijksoverheid.nl/onderwerpen/coronavirus-covid-19/crucialeberoepsgroepen?fbclid=IwAR2hPBTipZQBy3qY0JaPANA6HNlzC3FO4EqeGNZJ9ClrtY25aboCMbh $5 \mathrm{rc0}[24.03 .2020]$.

Rydzkowski W., Wojewódzka-Król K. (eds.) (2000), Transport, Wydawnictwo Naukowe PWN, Warszawa.

Sterman J.D. (2000), Business dynamics. System thinking and modelling for a complex world, Massachusetts Institute of Technology Engineering Systems Division Working Paper Series, ESD-WP2003-01.13-ESD Internal Symposium, Irwin / McGraw-Hill, Boston.

Sapovadia V.K. (2020), Terrestrial and celestial forces expose vulnerable economists. Financial crisis 2008 vs. 2020, SSRN 3547745 [28.03.2020].

Smith A. (1998 [1776]), An inquiry into the nature and causes of the wealth of nations, reprint edited with an introduction by Kathryn Sutherlands, Oxford University Press, Oxford.

Smith E. (2020), $60 \%$ to $70 \%$ of the German population will be infected by the coronavirus, Merkel says, CBNC, 11 March 2020, https://www.cnbc.com/2020/03/11/angela-merkel-most-people-will-getthe-coronavirus.html [26.03.2020].

Taleb N.N. (2005), Fooled by randomness. The hidden role of chance in life and in the markets, Random House, New York.

Taleb N.N. (2007), The Black Swan. The impact of the highly improbable, Penguin Books, London.

Taleb N.N. (2012), Antifragile. Things that gain from disorder, Penguin Books, London.

Taleb N.N., Read R., Douady R., Norman J., Bar-Yam Y. (2014), The precautionary principle. Fragility and black swans from policy actions, Extreme risk initiative - NYU School of Engineering Working Paper Series, https://arxiv.org/pdf/1410.5787.pdf [16.03.2020].

Tieleman R., Tieleman-Gu Y., Shi A.-J. (2020), Hollandse nuchterheid of Dutch ignorance?, 14 March 2020, https://www.linkedin.com/pulse/hollandse-nuchterheid-dutch-ignorance-robert-tieleman [15.03.2020].

Van de Mortel E. (2000), An institutional approach to transition processes Erasmus Universiteit Rotterdam, Rotterdam.

Vice M.S. (2020), Naomi Klein: coronavirus is the perfect disaster for disaster capitalism, 14 March 2020, https://migrate.readersupportednews.org/opinion2/277-75/61852-focus-naomi-klein-coronavirusis-the-perfect-disaster-for-disaster-

capitalism?fbclid=IwAR1PAs_NTyujTRSbgOSuz44W5EDa4zz4xo5j7jgBfyWB7Flv1TtjPyBOUIY [16.03.2020]. 
Johannes (Joost) PLATJE, Jeffrey A. HARVEY, Lez Rayman BACCHUS

Wilder-Smith A., Freedman D.O. (2020), Isolation, quarantine, social distancing and community containment. Pivotal role for old-style public health measures in the novel coronavirus (2019-nCoV) outbreak, "Journal of Travel Medicine", vol. 27 no. 2, p.taaa020. 